\title{
Short communication \\ Initial testing of electrospun nanofibre filters in water filtration applications
}

\author{
Decostere Bjorge ${ }^{1}$, Nele Daels', Sander De Vrieze², Pascal Dejans', Tamara Van Camp², Wim \\ Audenaert ${ }^{1}$, Philippe Westbroek ${ }^{2}$, Karen De Clerck ${ }^{2}$, Charlotte Boeckaert ${ }^{1}$ and Stijn WH van Hulle ${ }^{1^{*}}$ \\ ${ }^{1}$ Research Group EnBichem, Departement of Industrial Engineering and Technology, University College West Flanders, \\ Ghent University Association, Graaf Karel de Goedelaan 5, B-8500 Kortrijk, Belgium \\ ${ }^{2}$ Ghent University, Department of Textiles, Technologiepark 907, B-9052 Gent, Belgium
}

\begin{abstract}
The aim of this study was to evaluate the use of nanofibre microfiltration membranes, spun by an innovative electrospinning technique, in water filtration applications. As such, this study bridges the gap between developments in electrospinning techniques for the production of flat-sheet membranes and the application of these membranes in water filtration. Three different applications were examined. Firstly, the use of the membrane (functionalised or non-functionalised) for the removal of pathogens was investigated. Secondly, the electrospun flat-sheet membranes were applied for wastewater treatment in a laboratory-scale submerged membrane bioreactor (MBR). In addition to these applications, physical properties such as clean water permeability (CWP) and strength were also examined. The tests showed that the electrospun membranes can be used for water filtration applications, but that further improvements are necessary before these membranes can be practically employed. In particular, the level of functionality and the properties of irreversible fouling require further research.
\end{abstract}

Keywords: electrospinning, nanofibre, microfiltration, pathogen removal, MBR

\section{Nomenclature}

COD chemical oxygen demand $\left(\mathrm{mg} \mathrm{O}_{2} / \ell\right)$

CWP clean water permeability $\left(\ell / \mathrm{m}^{2} \cdot \mathrm{h} \cdot \mathrm{kPa}\right)$

DO dissolved oxygen $(\mathrm{mg} / \ell)$

IE inhabitant equivalent

MBR membrane bio reactor

MLSS mixed liquor suspended solids ( $\mathrm{mg} / \ell$ )

MLVSS mixed liquor volatile suspended solids (mg/ $\ell$ )

PA polyamide

PCTE polycarbonate track etched

PEI polyethylenimine

PETE polyethylene track etched

PPA polyacrylic acid

PSU polysulphone

PTFE polytetrafluoroethylene

TMP trans-membrane pressure $(\mathrm{kPa})$

TSS total suspended solids $(\mathrm{mg} / \ell)$

WSCP polydichloroethyl ether tetramethyl ethylene diamine (biocide)

\section{Introduction}

Electrospinning is a process that produces continuous ultrafine polymer fibres through the action of an external electric field imposed on a polymer solution or molten solution. Recently, polymer nanofibres have been attractive materials for a wide range of applications because of their large surface area to

\footnotetext{
* To whom all correspondence should be addressed.

푱 +32 (0) 56 241237; fax: +32 (0) 56241224 ;

e-mail: Stijn.Van.Hulle@,Howest.bo

Received 21 May 2009; accepted in revised form 17 November 2009.
}

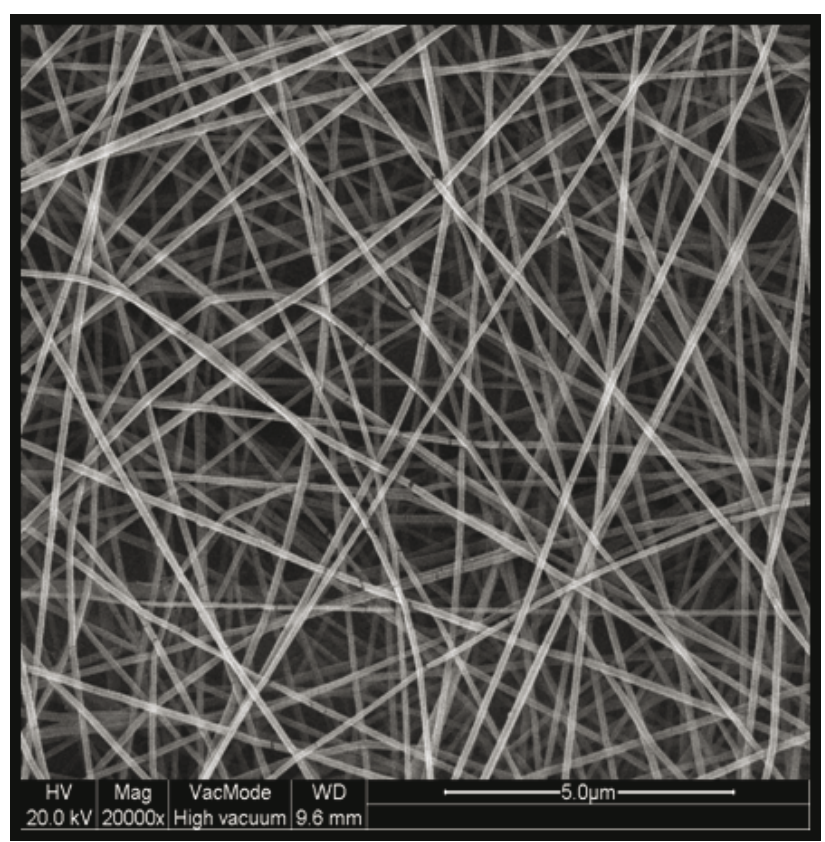

Figure 1

SEM picture of nanofibre polymer

volume ratio and the unique nanometre-scale architecture built by them (Fig. 1). Among the most successful methods for producing nanofibres is the electrospinning process (Huang et al., 2003).

One of the possible applications of nanofibres is water filtration. For this application a nanofibre flat-sheet membrane can be produced that can be used as a water filtration membrane. More specifically, this can be used in microfiltration. Due to 
their higher porosities and interconnected pore structures, nanofibres offer a higher permeability to water filtration than conventional materials currently in use (Thavasi et al., 2008). This study aims at assessing the possible use of electrospun nanofibre filters in water filtration. Firstly, physical properties such as clean water permeability (CWP) and strength were examined. Secondly, the use of the membrane (functionalised or non-functionalised) for the removal of pathogens was investigated and compared to previous studies. Thirdly, the application of the electrospun membranes for wastewater filtration in a submerged MBR was investigated.

\section{Methods}

\section{Membrane production process}

The standard set-up for electrospinning consists of a spinneret with a metallic needle, a syringe pump, a high-voltage power supply, and a grounded collector. A polymer, sol-gel, composite solution (or molten mixture) is loaded into the syringe and this liquid is driven into the needle tip by a syringe pump, forming a droplet at the tip. When a voltage is applied to the needle, the droplet is first stretched into a structure called the Taylor cone. If the viscosity of the material is sufficiently high, varicose breakup does not occur and an electrified liquid jet is formed. (If varicose breakup does occur, droplets are electro-sprayed.) The jet is then elongated and whipped continuously by electrostatic repulsion until it is deposited on the grounded collector (Doshi and Reneker, 1995). At Ghent University a scaled-up multinozzle system has been developed. A conveyor belt (conductor) shifts an aluminium foil horizontally, on which the nanofibre is deposited. At the same time the needle module moves back and forth to achieve smooth deposition. Polyamide (PA) proved to be most suitable for electrospinning in contrast with PAA, PSU and PEI. It can be electrospun under steady-state conditions (De Vrieze et al., 2009) This production process results in a flat-sheet non-woven nanofibre membrane with a mean pore size of $0.4 \mu \mathrm{m}$ (as measured with a bubble point test (Mulder, 1992)) a fibre diameter between 50 and $100 \mathrm{~nm}$ and a thickness of $120 \mu \mathrm{m}$.

\section{Membrane functionality process}

Several methods for functionalising the membrane with silver nanoparticles or other biocides were examined. The $1^{\text {st }}$ method was impregnation by reduction of silver nitrate $\left(\mathrm{AgNO}_{3}\right)$. A $2^{\text {nd }}$ method was the addition of silver nanoparticles or biocides (such as WSCP) to the polymer solution before electrospinning. In this way the biocides are impregnated into the membrane (Daels et al., 2009).

\section{Removal of pathogens}

To evaluate the removal of pathogens, different water samples were taken: wastewater from a general hospital (Ziekenhuis Hogerlucht, Ronse Belgium), water from a local pond, and collected rainwater. These samples were filtered with a pressure filter (100 to $150 \mathrm{kPa}$ ). Further, the culturable micro-organisms were enumerated by inoculation in a nutrient agar culture medium at $22^{\circ} \mathrm{C}$ and $37^{\circ} \mathrm{C}$ (EN ISO 6222:1999). The coliform bacteria were detected and enumerated (EN ISO 9308-1:2000). The removal of pathogens was expressed as a $\log _{10}$ value.

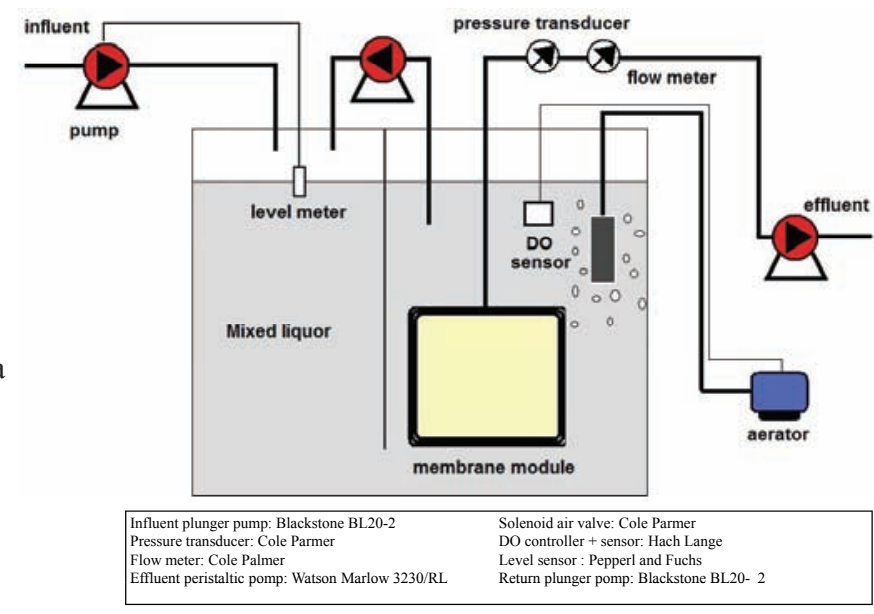

Figure 2

Schematic representation of the MBR

\section{Evaluation of the physical characteristics}

Clean water permeability (CWP) represents the maximum flux achievable, dependent on the state of the membrane. It can be determined by measuring the flux at different TMPs. The slope of the resulting curve is considered as the CWP (Mulder, 1992). The CWP test was performed at $20^{\circ} \mathrm{C}$. A support layer was applied to prevent micro-cracks in the membrane. A tensiontesting machine (Chatillon TCD 200) was used to examine the tensile strength of the nanofibre membrane. A specific test strip $(50 \mathrm{~mm})$ was stretched at a pulling speed of $50 \mathrm{~mm} / \mathrm{min}$ until rupture. This resulted in the maximum tensile strain. The test was executed in different places and directions and in wet and dry condition of the membrane. In addition, the differences between the nanofibre and a commercial PA membrane $(0.45$ $\mu \mathrm{m})$ as well as a commercial Teflon membrane $(0.2 \mu \mathrm{m})$ were evaluated. The tensile strength test was performed at $20^{\circ} \mathrm{C}$.

\section{Nanofibre membrane used in a submerged MBR}

Another application that was examined was the use of the nanofibre membrane in a submerged MBR. Therefore, a fullyautomated laboratory-scale MBR (semi-deadend) was built (Fig. 2).

The membrane module consisted of a central part and 2 side parts produced in PVC. The nanofibre membrane was pressed between the central part and the side part. As such, 2 filtration surfaces were created, both with a surface area of $0.037 \mathrm{~m}^{2}$ (height: $23 \mathrm{~cm}$ and width: $16 \mathrm{~cm}$ ). A stainless steel grid was used as spacer on both sides of the membrane. The design parameters of the reactor are presented in Table 1.

\begin{tabular}{|l|c|c|c|}
\hline \multicolumn{4}{|c|}{ Table 1 } \\
Design parameters \\
\hline Design parameter & $\begin{array}{c}\text { Abbre- } \\
\text { viation }\end{array}$ & Unit & Value \\
\hline Total reactor volume & $\mathrm{V}$ & 1 & 50 \\
\hline Hydraulic residence time & $\mathrm{HRT}$ & $\mathrm{d}$ & 0.5 \\
\hline Recycle ratio (return/feed) & $\mathrm{R}$ & - & $3 / 1$ \\
\hline Ratio aerobic/anoxic & $\mathrm{V} / \mathrm{V}$ & - & $2 / 1$ \\
\hline Filtering surface & $\mathrm{A}$ & $\mathrm{m}^{2}$ & 0.073 \\
\hline Membrane flux & - & $\ell / \mathrm{m}^{2} \cdot \mathrm{h} \cdot \mathrm{kPa}$ & 0.3 \\
\hline
\end{tabular}

The reactor was constructed according to a pre-denitrification configuration (Tchobanoglous et al., 2003). The $1^{\text {st }}$ 
zone of the reactor was an anoxic zone, the $2^{\text {nd }}$ an aerobic zone. The forced aeration in the aerobic zone was achieved by compressed air at $700 \mathrm{kPa}$ through a diffuser. Due to the hydrostatic pressure in the reactor and the lower pressure on the effluent side, the sludge/water mixture was pumped through the membrane. A level sensor was placed to prevent the reactor from overflowing or running empty if problems did occur. The reactor was inoculated with activated sludge from a municipal wastewater treatment plant treating the wastewater of 10000 IE. The reactor was fed with synthetic wastewater, the components of which are presented in Table 2 . This feed was led through a dividing wall in the aerobic zone of the reactor. The dissolved oxygen (DO) in this zone was controlled between 3.9 and $4.1 \mathrm{mg} \mathrm{O}_{2} / \ell$ using forced aeration. In the aerobic zone, 2 mechanisms took place: COD removal and nitrification.

\begin{tabular}{|l|l|}
\hline $\begin{array}{c}\text { Table } 2 \\
\text { Compounds of the synthetic feed } \\
\text { prepared with tap-water }\end{array}$ \\
\hline Component & Concentration \\
\hline Glucose & $200 \mathrm{mg} \mathrm{O} / \ell$ \\
\hline$\left(\mathrm{NH}_{4}\right)_{2} \mathrm{SO}_{4}$ & $30 \mathrm{mg} \mathrm{N} / \ell$ \\
\hline $\mathrm{KH}_{2} \mathrm{PO}_{4}$ & $6 \mathrm{mg} \mathrm{P} / \ell$ \\
\hline $\mathrm{NaHCO}_{3}$ & $200 \mathrm{mg} \mathrm{CaCO} / \ell$ \\
\hline
\end{tabular}

The water was pumped into the anoxic zone where denitrification took place. Due to the fouling on the membrane TMP increased. At a set point of 30 to $40 \mathrm{kPa}$ backwashing with a flux of $27 \mathrm{l} / \mathrm{m}^{2} \cdot \mathrm{h}$ was performed. The process was monitored and controlled with a Phoenix Contact Programmable Logic Controller. The DO in the reactor, flux and TMP were continuously registered on a PC. The online registration of TMP and flux allowed the evaluation of the rate of fouling and the condition of the membrane. Registration of DO gave an indication of the microbiological activity of the sludge. The MBR was operated at $20^{\circ} \mathrm{C}$.

\section{Results and discussion}

\section{Evaluation of the physical characteristics}

The CWP was determined by measuring the flux at different trans-membrane pressures (TMP). The slope of the resulting curve is considered as the CWP $\left(\ell / \mathrm{m}^{2} \cdot \mathrm{h} \cdot \mathrm{kPa}\right)$. The slope of the curve equalises the CWP which is $66.51 \ell / \mathrm{m}^{2} \cdot \mathrm{h} \cdot \mathrm{kPa}$ for the nanofibre membrane. The CWP value of other commercial polymer membranes (PETE, PCTE and PTFE) used for microfiltration was also determined and ranged from 20 to 30 $\ell / \mathrm{m}^{2} \mathrm{~h} \cdot \mathrm{kPa}$. As such, the CWP value of the nanofibre membrane is high in comparison to the commercial polymer membranes. This could be useful in treating large volumes of water in the absence of particles that could obstruct the nanofibre membrane. In addition, this high CWP indicates that nanofibre membranes could be energy saving (Thavasi et al., 2008).

The strength test in different conditions and different directions of the membrane revealed the tensile strength of the nanofibre $\left(149+/-38 \mathrm{~kg} \cdot \mathrm{cm}^{2}\right)$ to be comparable with a commercial Teflon (PTFE) membrane $\left(142+/-61 \mathrm{~kg} \cdot \mathrm{cm}^{2}\right)$.

\section{Removal of pathogens}

\section{Non-functionalised membrane}

The enumeration of culturable micro-organisms $\left(37^{\circ} \mathrm{C}, 22^{\circ} \mathrm{C}\right)$ and coliform bacteria showed that the removal of pathogens

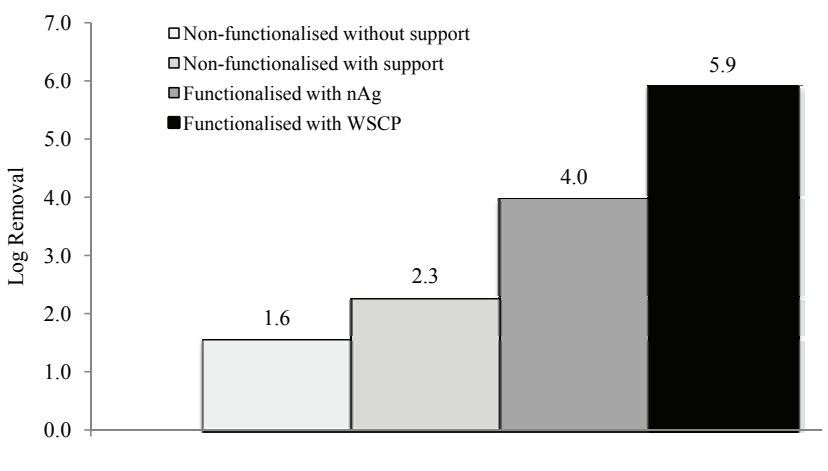

Figure 3

Removal of culturable organisms at $37^{\circ} \mathrm{C}$

was low compared to other microfiltration membranes, both for culturable micro-organisms $\left(1.5 \log _{10}\right)$ and for coliform bacteria $\left(1.5 \log _{10}\right)$. With other commercial microfiltration membranes a $2 \log _{10}$ to $4 \log _{10}$ removal is possible (Gómez et al., 2006, Sadr Ghayeni et al., 1999, Zodrow et al., 2009). At first this low removal was explained by the fact that the support plate of the pressurised filter module had rather large (1 to $2 \mathrm{~mm}$ ) openings, which resulted in the creation of micro-cracks in the membrane due to the pressure. Therefore, the tests were repeated with a support layer. With this support layer a $2 \log _{10}$ was achieved. This result is still below those reported from other microfiltration studies, and can be explained as follows: First, there is the possibility of the presence of a small number of pores with an abnormally large size relative to the average pore size and which are not detected by currently available characterisation methods (Gomez et al., 2006). Secondly, and most likely, it could be assumed that the TMP causes a deformation of the nanofibres so that the pore size increases and bacteria leak through the membrane.

\section{Functionalised membrane}

The filtration tests with functionalised nanofibre membranes show that a higher efficiency ( $4 \log _{10}$ to $6 \log _{10}$ ) could be achieved. In Fig. 3, the comparison between non-functionalised and functionalised membranes is depicted. With silver nanoparticles $(\mathrm{nAg})$ a $4 \log _{10}$ removal can be achieved, while with a commercial biocide (WSCP) a $6 \log _{10}$ can be achieved. The lower removal of pathogens with silver nanoparticles can be explained by the fact that silver nanoparticles only have a biocidal effect on gram-negative bacteria such as E. coli (Sondi and Salopek-Sondi, 2004). Thus the gram-positive bacteria survive and may leak through the membrane.

Currently, tests are being performed to assess the pathogen removal performance of nanofibre membranes functionalised with different biocides at different concentrations. This should give an overview of the pathogen-removal capacity of these functionalised membranes. Tests are also being performed to determine the retention of the biocide on the membrane, although initial tests have suggested that a good retention can be achieved.

\section{Nanofibre membrane used in a submerged MBR}

Initial tests showed that the membrane was not strong enough to resist the vacuum pressure of the effluent pump, which increased due to the fouling on the membrane. At first only a 5 -d working period could be guaranteed. Changes were made to increase the tensile strength of the membrane and also to 


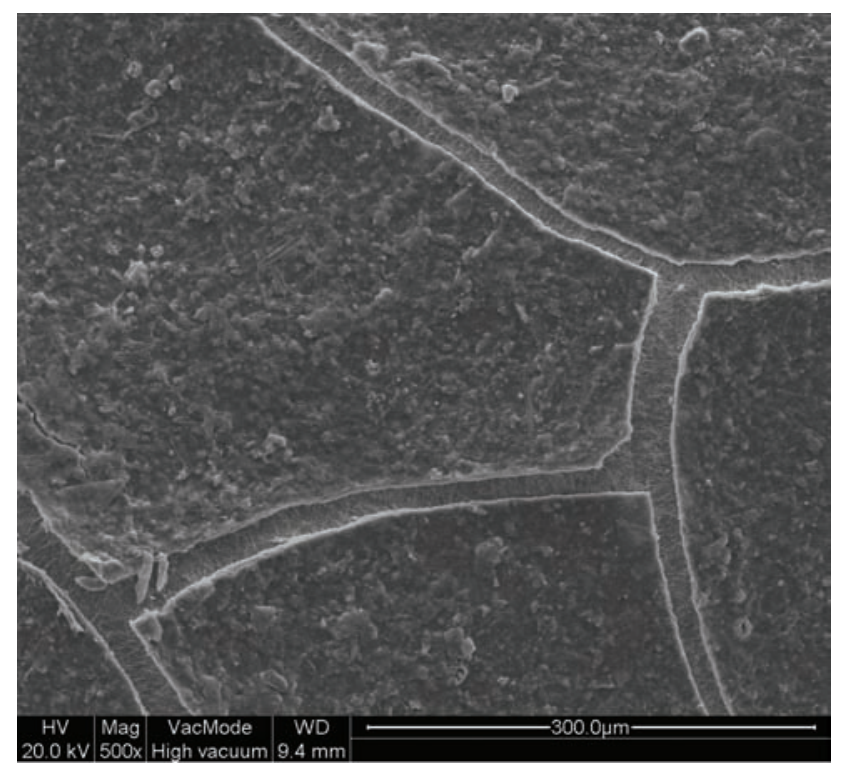

Figure 4

SEM photo of the clogged membrane

increase the thickness of the membrane, which allowed a working period of at least $59 \mathrm{~d}$. With a few exceptions, the flux through the membrane was stable $\left(0.3 \mathrm{l} / \mathrm{m}^{2} \cdot \mathrm{h} \cdot \mathrm{kPa}\right)$ during the experiment. However, due to the high fouling rate of the membrane, the backwashing frequency was 2 to $10 / \mathrm{hr}$. This is rather high compared to other studies, in which flat-sheet membranes (Kubota) were used; a backwashing frequency of only $1 / \mathrm{hr}$ was reported by Yang et al. (2006).

Although backwashing with permeate removed the reversible fouling, a persistent yellow layer could not be removed. This irreversible fouling caused a rapid decay of the membrane flux after only $7 \mathrm{~d}$ and was clearly visible in the SEM pictures taken after $14 \mathrm{~d}$ of operation (Fig. 4). This 'layered' clogging of electrospun nanofibres was also observed by Aussawasathien et al. (2008); minimisation of this clogging requires further research and operational optimisation.

Cleaning the membrane with demineralised water was not sufficient to restore the flux to its original level. Therefore a sequential chemical cleaning with $\mathrm{NaOCl}(0.5 \%)$ and $\mathrm{HCl}$ $(0.1 \%)$ was used (Lim and Bai, 2003). Even with the chemical cleaning procedure, the original flux could not be achieved, and following the cleaning phase a similar decay of the flux could be observed. It is therefore concluded that further membrane development should take place, and that additional measures, such as membrane performance enhancement products or other process configurations (pre-filtration with a trickling filter or cross-flow operation), should be used.

The online registration of the DO showed good bacterial activity throughout the process. The MLSS increased from $1 \mathrm{~g} / \ell$ to $3.940 \mathrm{~g} / \ell$ and the MLVSS from $0.6 \mathrm{~g} / \ell$ to $3.152 \mathrm{~g} / \ell$ during the 59-d period. Other important parameters that were monitored were the removal of $\mathrm{NH}_{4}^{+}, \mathrm{COD}, \mathrm{TSS}, \mathrm{NO}_{3}$ and turbidity. Very good removal of turbidity (99.25\%), TSS (99.71\%), COD $(94.73 \%)$ and $\mathrm{NH}_{4}^{+}(93.98 \%)$ was achieved, with only the removal of total nitrogen $\left(\mathrm{NH}_{4}^{+}\right.$and $\left.\mathrm{NO}_{3}^{-}\right)$ being unsatisfactory. This was due to unsatisfactory denitrification. Turbidity and SS are generally related to the membrane performance and efficiency. These parameters were reduced to, on average, 3 NTU and $3.7 \mathrm{mg} / \ell$. Several measures were taken to improve the denitrification. At first the recycle ratio of the reactor was increased, which resulted in a minor enhancement. Lowering the DO in the reactor (2 to $3 \mathrm{mg} / \ell$ ) seemed to not have any influence at all. Due to the fact that the residual COD is indicative of the remaining substrate available for the denitrification process it could be of interest in future research to increase the COD. This will be examined in further tests.

\section{Conclusions}

For the removal of pathogens, it can be concluded that in the case of non-functionalised membranes the removal efficiency is not satisfactory $\left(2 \log _{10}\right.$ removal). This could be explained by the fact that the TMP causes changes in the non-woven membrane structure which leads to the enlargement of the pores and allows bacteria to pass through the membrane.

Functionalisation with silver nanoparticles gave a $4 \log _{10}$ removal, while functionalisation with a biocide (WSCP) gave a $6 \log _{10}$ removal. The lower removal of pathogens with silver nanoparticles can be explained by the fact that the silver nanoparticles only have a biocidal effect on gram-negative bacteria. It can be concluded that pathogen removal with functionalised nanofibre membranes is higher than pathogen removal with commercial microfiltration membranes ( $2 \log _{10}$ to $\left.4 \log _{10}\right)$. In future it would be interesting to optimise the removal of pathogens with the functionalised membrane. The CWP suggests that large volumes could be treated if fouling does not occur. It is likely that this membrane could be highly useful as a pre-treatment in the production process for process- and cooling-water, as protection for the reverse osmosis installation (Bonnélye et al., 2008).

The use of the nanofibre membrane in a submerged MBR suggested that, due to the irreversible fouling which causes a rapid decay of the flux, the membrane is not competitive with the known commercial membranes. Other process configurations such as pre-filtration or cross-flow operation should be used. Overall it can be concluded that nanofibre filters have potential in water filtration applications but that several improvements are still required before these filters can be practically employed.

\section{Acknowledgements}

The authors would like to thank the Institute for the Promotion of Innovation by Science and Technology in Flanders (IWT) for their financial support (IWT-Tetra Project Contract Nos. 060113 and 080148). The help of Imca Sampers and Caroline Vandenbussche with the microbial analysis is greatly appreciated.

\section{References}

AUSSAWASATHIEN D, TEERAWATTANANON C and VONGACHARIYA A (2008) Separation of micron to sub-micron particles from water: Electrospun nylon-6 nanofibrous membranes as pre-filters. J. Membrane Sci. 315 11-19.

BONNÉLYE V, GUEY L and DEL CASTILLO J (2008) UF/MF as RO pre-treatment: the real benefit. Desalination 222 59-65.

DAELS N, DECOSTERE B, DE VRIEZE S, DEJANS P, VAN CAMP T, AUDENAERT W, HOGIE J, WESTBROEK P, DE CLERCK K and VAN HULLE SWH (2009) Performance assessment of functionalized electrospun nanofibres for removal of pathogens. Proc. 1st IWA BeNeLux Regional Young Water Professionals Conf., 30 September - 2 October 2009, Eindhoven, the Netherlands. 
DE VRIEZE S, WESTBROEK P, VAN CAMP T and DE CLERCK K (2009) Solvent system for steady state electrospinning of polyamide 6.6. J. Appl. Polym. Sci. 115 837-842.

DOSHI J and RENEKER DH (1995) Electrospinning process and applications of electrospun fibers. J. Electrostat. 35 151-160.

EN ISO 6222:1999. Water quality - Enumeration of culturable microorganisms - Colony count by inoculation in a nutrient agar culture medium.

EN ISO 9308-1:2000. Water quality - Detection and enumeration of Escherichia coli and coliform bacteria-Part 1: Membrane filtration method.

GÓMEZ M, DE LA RUA A, GARRALÓN G, PLAZA F, HONTORIA E and GÓMEZ MA (2006) Urban wastewater disinfection by filtration technologies. Desalination 190 16-28.

HUANG Z-M, ZHANG Y-Z, KOTAKI M and RAMAKRISHNA S (2003) A review on polymer nanofibres by electrospinning and their applications in nanocomposites. Comp. Sci. Technol. 63 2223-2253.

LIM AL and BAI R (2003) Membrane fouling and cleaning in microfiltration of activated sludge wastewater. J. Membrane Sci. 216 279-290.
TCHOBANOGLOUS G, BURTON FL and STENSEL HD (2003) Wastewater Engineering Treatment and Reuse (4th edn.). Metcalf \& Eddy Inc, McGraw-Hill, New York.

MULDER M (1992) Basic Principles of Membrane Technology. Kluwer Academic Publishers, Dordrecht.

SADR GHAYENI SB, BEATSON AJ and SCHNEIDER RP (1999) Bacterial passage through microfiltration membranes in wastewater applications. J. Membrane Sci. 153 71-82.

SONDI I and SALOPEK-SONDI B (2004) Silver nanoparticles as antimicrobial agent: a case study on $E$. coli as a model for Gram negative bacteria, J. Colloid Interface Sci. 275 177-182.

THAVASI V, SINGH G and RAMAKRISHNA S (2008) Electrospun nanofibres in energy and environmental applications: Tools and Resources. Energ. Environ. Sci. 1 205-221.

YANG W, CICEK N and ILG J (2006). State-of-the-art of membrane bioreactors: Worldwide research and commercial applications in North America. J. Membrane Sci. 270 201-211.

ZODROW K, BRUNET L, MAHENDRA S, LI D, ZHANG A, LI Q and ALVAREZ PJJ (2009) Polysulfone ultrafiltration membranes impregnated with silver nanoparticles show improved biofouling resistance and virus removal. Water Res. 43 715-723. 
Available on website http://www.wrc.org.za ISSN 0378-4738 (Print) = Water SA Vol. 36 No. 1 January 2010 ISSN 1816-7950 (On-line $)=$ Water SA Vol. 36 No. 1 January 2010 